\title{
Gene wars escalate as US official battles NIH over pursuit of patent
}

Washington. A leading US government lawyer has blocked the National Institutes of Health (NIH) from continuing to pursue patents on thousands of partial cDNA sequences, a controversial - and by some accounts illegal - move that reflects a bitter battle within the government. The decision by Michael Astrue, general counsel for the Department of Health and Human Services (HHS), NIH's parent agency, is intended to thwart Bernadine Healy, the $\mathrm{NIH}$ director, and reflects the views of critics of gene patenting, including much of the biotechnology industry.

Last week, Astrue told HHS officials that he would not permit NIH to respond to the US Patent and Trademark Office's rejection on 20 August of its application. NIH had intended to answer the patent office's decision within the next several months, and Healy told Congress last month that her legal experts believed that the agency could win its case (see Nature 359, 263; 1992).

Astrue's tactics shows how divisive the gene patent issue has become and the lengths to which opponents are willing to go to undermine the $\mathrm{NIH}$ position. At one point, the patent office became so frustrated with conflicting instructions from warring factions within the government that it warned the government that it would henceforth communicate only with NIH's law firm, Knobbe, Martens, Olson \& Bear of Newport Beach, California.

The leading critic of NIH's patent application within the Bush administration, Astrue believes that gene sequences with unknown functions should not be patented because such patents would hinder companies from developing gene-based products. Over the past several months, he has tried repeatedly to prevail against the objections of Healy and, in the latest case, even his own boss, Louis Sullivan, the HHS secretary.

Before the patent office had even completed its initial review this summer, Astrue asked it to suspend consideration of the application on policy grounds. In a letter of 18 June to Harry Manbeck, the US patent commissioner, Astrue said that "I have concluded that [the NIH applications] do not satisfy the threshold legal requirements for an invention because they do not describe the use or function of the sequences." NIH officials - who were not told of Astrue's letter before it was sent - protested that his request was an attempt to sabotage the application.

They need not have worried. The patent office, arguing that the case was too important to drop, rejected Astrue's request. In a letter to Astrue on 25 June, patent officials said that "the strong public interest in identifying and resolving any issue of patentability presented in these applications" demanded their prompt consideration. Manbeck warned Astrue that his "apparent conclusion that some, as yet unidentified,

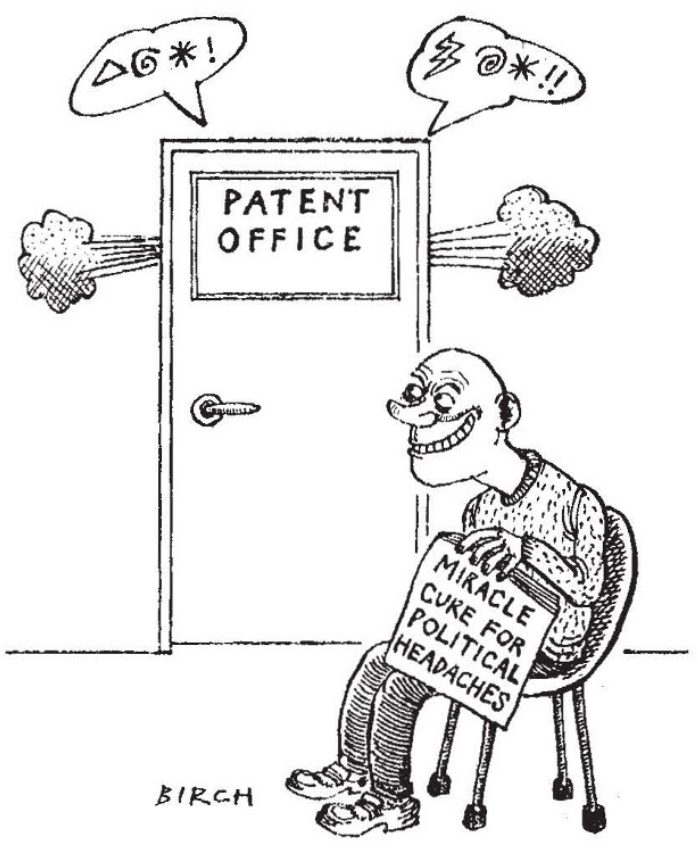

portion of the applications does not meet the legal threshold for a patentable invention" was simply inappropriate. If Astrue had additional information - rather than simply an opinion - on the patent claim, he should have submitted it, the patent official scolded.

The rebuke did not deter Astrue. After NIH's application was refused in August, he ordered the agency not to release or discuss the arguments made by the patent office. When Healy requested permission to bring up the subject in congressional testimony last month, Astrue and the Office of Management and Budget (OMB) deleted references to the decision from her written testimony. Healy nevertheless defied the order and discussed the issue in her oral testimony, but it was a risky move that may have hurt her politically.

Some observers attribute Astrue's fervour to both his personal beliefs and the fact that he will be leaving the government next month for a job in which a reputation for gene-patent busting may serve him well. Although he is prohibited by federal law from handling biotechnology issues for one year, he plans to resume his campaign at the first opportunity in the course of representing industrial clients as a member of a Boston-based law firm. Astrue, contacted last week, declined to comment on the issue.

Despite his imminent departure, Astrue believes that his arguments will prevail, telling associates that he has the support of officials at OMB and the White House Council on Competitiveness, which under Vice President Dan Quayle has become a powerful mechanism for industry to influence government policy (see Nature 353, 198; 1991). A spokesman for the Council said that it had no policy on gene patents and would not confirm that it had discussed the issue with Astrue.

But just how Astrue can defy his own boss is not clear. Sullivan supports Healy on this issue and last month allowed NIH to file for patents on additional cDNA partial sequences. "Mike Astrue is not Secretary Sullivan; he's just one part of this", says a spokesman for the department. Astrue is claiming that the department is required to take the advice of its ranking legal authority, arguing that NIH made its application in "bad faith" and that pursuing it would constitute legal malpractice.

Richard Godown, the president of the Industrial Biotechnology Association (IBA), says it would be "very unusual" for Sullivan or the acting HHS general counsel to overrule Astrue's decision after he leaves. Nor would Godown want them to. Although the IBA backed NIH's original filing, Godown says that was done only to prevent individual NIH scientists from applying for the patents privately, something IBA felt would set an even worse precedent. Godown hopes that the last word on the matter - the patent office's interim rejection - will stand unchallenged and will discourage further attempts to patent unknown genes.

Whatever the resolution of the legal questions, it is not clear what is to be gained by blocking NIH from pursuing its patent bid. Private companies and individuals are rumoured to have filed for similar gene patents, and they are not likely to abandon their applications even if NIH does. The patent office itself has asked to take the subject through a full exchange of arguments to its conclusion, so as to leave a final decision as precedent. The US government's internal battle over gene patents may produce casualties, but it seems unlikely to end the war.

Christopher Anderson 